\title{
Uji Kandungan Logam Berat Pb Dan Hg Pada Air, Sedimen Dan Lamun (Enhalus acoroides) Di Perairan Teluk Kayeli Kabupaten Buru Provinsi Maluku
}

\author{
Nur Alim Natsir'1, Debby A. J Selanno², Ch.I. Tupan ${ }^{3}$, Y.T.Male ${ }^{4}$ \\ ${ }^{1}$ Program Studi Pendidikan Biologi, Fakultas Ilmu Tarbiyah dan Keguruan \\ Institut Agama Islam Negeri Ambon \\ 2,3 Jurusan Manajemen Sumberdaya Perairan, Fakultas Perikanan dan Ilmu Kelautan, \\ Universitas Pattimura Ambon \\ ${ }^{4}$ Jurusan Kimia, Fakultas Matematika dan Ilmu Pengetahuan Alam \\ Universitas Pattimura Ambon \\ ${ }^{1}$ Email: nuralimnatsir@gmail.com \\ ${ }^{2}$ Email: debby_st@yahoo.co.id \\ ${ }^{3}$ Email: lotjetupan@yahoo.com \\ ${ }^{4}$ Email: yusmale@fmipa.unpatti.ac.id
}

\begin{abstract}
Abstrak: Perbedaan akumulasi logam berat timbal dan merkuri pada air, sedimen dan organ lamun Enhalus acoroides (akar, rhizoma dan daun) ditemukan di perairan Teluk Kayeli Pulau Buru Provinsi Maluku. Sampel diambil dari sepuluh stasion pengamatan (Muara Sungai Kayeli,Muara Sungai Suket, Muara Sungai Anahoni, Muara Sungai Waelata I, Muara Sungai Waelata II, Muara Sungai Waeapo, Muara Sungai Sanleko, Muara Sungai Marlosso,Pantai Nametek dan Pantai Jikumerasa). $\mathrm{Pb}$ dan $\mathrm{Hg}$ di analisis menggunakan Atomic Absorption Spectrophotometer. Kandungan $\mathrm{Pb}$ dan $\mathrm{Hg}$ di sedimen lebih tinggi daripada di air. Kandungan $\mathrm{Pb}$ dan $\mathrm{Hg}$ tertinggi ditemukan pada akar kemudian pada rhizoma dan daun (akar > rhizoma > daun). Lamun Enhalus acoroides merupakan salah satu organisme hidup yang dapat dijadikan sebagai bioindikator tingkat pencemaran logam berat dalam lingkungan perairan.
\end{abstract}

\section{Kata Kunci: Enhalus acoroides, Pb, Hg, Bioakumulasi, Bioindikator}

\begin{abstract}
The difference in accumulation of lead and mercury heavy metals in water, sediments and seagrass organs Enhalus acoroides (roots, rhizomes and leaves) is found in the waters of Kayeli Bay, Buru Island, Maluku Province. Samples were taken from ten observed station (Kayeli River Estuary, Suket River Estuary, Anahoni River Estuary, Waelata I Estuary, Waelata River Estuary II, Waeapo River Estuary, Sanleko River Estuary, Marlosso River Estuary, Nametek Beach and Jikumerasa Beach). $\mathrm{Pb}$ and $\mathrm{Hg}$ were analyzed using Atomic Absorption Spectrophotometer. The content of $\mathrm{Pb}$ and $\mathrm{Hg}$ in sediments is higher than in water. The highest $\mathrm{Pb}$ and $\mathrm{Hg}$ content is found in the roots then in the rhizoma and leaves (roots> rhizoma> leaves). Seagrass Enhalus acoroides is
\end{abstract}

BIOLOGI SEL (VOL 8 NO 1 EDISI JAN-JUN 2019 ISSN 2252-858X/E-ISSN 2541-1225) PAGE 9 
one of the living organisms that can be used as a bio-indicator of the level of heavy metal pollution in the aquatic environment.

Key Words: Enhalus acoroides, Pb, Hg, Bioakumulasi, Bioindicator

Pencemaran lingkungan pesisir dan lautan menjadi masalah global, terutama di negara maju dan berkembang. Polusi di daerah pantai dan laut umumnya terjadi karena pembangunan industri dan kegiatan pariwisata di daerah pesisir. Dampak dari kegiatan ini akan cenderung meningkatkan jumlah sampah yang dibuang ke perairan. Logam berat termasuk limbah berbahaya yang berperan sebagai sumber polusi, yang umumnya beracun. Mengingat potensi efek merugikan terhadap lingkungan dan kesehatan manusia, zat-zat ini jadi perhatian besar untuk studi lebih lanjut (Rainbow, 2007; Roberts et al., 2008). Limbah logam berat merupakan limbah yang paling berbahaya karena menimbulkan efek racun bagi manusia (Boran dan Altinok, 2010). Pencemaran logam berat yang masuk ke lingkungan perairan akan terlarut dan akan terakumulasi dalam sedimen ataupun biota dan dapat bertambah sejalan dengan berjalannya waktu, tergantung pada kondisi lingkungan perairan tersebut (Wulandari et al., 2012: Rijal, M et al., 2014). Bioakumulasi logam dalam suatu organisme laut merupakan langkah pertama sebelum organisme tersebut menunjukkan responnya terhadap pencemar atau kontaminan dan siklus geokimia (Fisher, 2003). Proses bioakumulasi logam berat secara kimiawi merupakan reaksi reaksi pembentukan senyawa komplek antara logam berat dengan selsel organisme yang berfungsi sebagai ligan. Proses ini diterangkan melalui teori Ligan Biotic Model yaitu: ion logam bebas atau derivatnya dirancang untuk memprediksikan bagaimana logam berat tersebut berinteraksi dengan organisme akuatik (Campbell, 2002).

Lamun adalah salah satu jenis vegetasi yang mampu hidup dan berkembang dengan baik di kawasan pesisir serta menjadi habitat beberapa jenis hewan laut, seperti: teripang, landak laut, bintang laut, dan bulu babi. Lamun merupakan kelompok tumbuhan berbiji tunggal (monokotil) dari kelas angiospermae dan mempunyai fungsi ekologis yang sangat besar. Lamun biasanya terdapat dalam jumlah yang cukup besar dan dapat membentuk suatu padang lamun yang rapat, menutupi suatu area yang luas pada daerah pesisir di daerah subtropis dan daerah tropis. Lamun merupakan produsen primer di laut yang cukup besar bila dibandingkan dengan ekosistem lainnya (Azkab, 2006). Daun, yang umumnya berbentuk pita, bertindak sebagai perangkap bahan tersuspensi yang dibawa oleh arus ke daerah padang lamun. Rhizoma dan sistem perakarannya dapat menstabilkan sedimen sehingga dapat mencegah erosi, terutama saat terjadi badai, hujan dan banjir (Björk et al. 2008). Penelitian mengenai kemampuan vegetasi perairan, baik lamun maupun makro alga dalam mengakumulasi logam berat telah diteliti sebelumnya oleh (Endang, 2008; Ahmad et al., 2015; Ambo-Rappe et.al., 2011; Sudharsan et al., 2012; Supriyantini et al., 2016; Thangaradjou et al., 2010; Tupan dan Azrianingsih, 2016) 
yang menemukan bahwa lamun merupakan salah satu cara untuk menentukan tingkat cemaran di perairan laut. Lamun merupakan suatu penanda kapasitas akumulasi logam karena berinteraksi secara langsung dengan badan air dan air tanah (substrat) melalui daun dan akarnya untuk uptake ion-ion sehingga lamun dapat merefleksikan status kesehatan perairan secara keseluruhan (Ahmad et al., 2015; Supriyantini et al., 2016).

Teluk Kayeli merupakan perairan yang terdapat di Kabupaten Buru Provinsi Maluku dan terletak antara $3^{0} 15^{\prime} 55^{\prime},-3^{0} 22^{\prime} 50^{\prime \prime} \mathrm{S}$ dan $127^{0} 01{ }^{\prime} 35^{\prime \prime}-127^{0} 01{ }^{\prime} 35^{\prime \prime} \mathrm{T}$ yang. Perairan ini rentan mengalami kontaminasi logam berat. Hal ini diakibatkan oleh aktivitas pertambangan emas tradisional yang beroperasi di kawasan aliran Sungai Waeapo dan bermuara langsung ke Teluk Kayeli. Pertambangan illegal yang tidak terkendali di daerah ini akan mengancam kelestarian lingkungan. Lingkungan yang tercemar oleh limbah bahan kimia pertambangan akan berdampak pada lahan pertanian, pencemaran laut serta dalam jangka penjang dapat mengancam kesehatan penduduk setempat karena mengkonsumsi air serta bahan pangan yang telah tercemari logam berat (Tuaputty, 2014). Agus et al. (2005) dan Ning et al. (2011) melaporkan bahwa pertambangan emas tradisional merupakan salah satu sumber masuknya logam berat ke dalam lingkungan perairan.Penelitian tentang status pencemaran logam berat di wilayah perairan Teluk Kayeli Kabupaten Buru masih terus dilakukan baik pada air, sedimen maupun lamun (Enhalus acoroides). Tujuan dalam penelitian ini adalah untuk menganalisis kandungan logam berat $\mathrm{Pb}$ dan $\mathrm{Hg}$ di air, sedimen dan organ lamun Enhalus acoroides (akar, rhizoma dan daun).

\section{METODE PENELITIAN}

\section{Penentuan Titik dan Pengambilan Sampel}

Penetapan titik pengambilan sampel menggunakan Geographic Positioning System (GPS) merek Garmin. Penetapan titik pengambilan sampel dilakukan secara sengaja yakni dengan pertimbangan daerah aliran bahan pencemar dari sumber dan potensi sasaran yang terkena dampak di perairan. Stasiun pengambilan sampel dibagi menjadi 9 titik sampling dan satu titik sampling yang mewakili daerah yang jauh dari sumber pencemar. Stasion 1 (Muara Kayeli) terdapat kegiatan di darat (dermaga, pemukiman, pertambangan (tromol)); Stasion 2 (Muara Suket) terdapat mangrove dan tidak terdapat kegiatan darat; Stasion 3 (Muara Anahoni) tidak terdapat kegiatan di darat namun merupakan aliran pembuangan limbah pertambangan emas (sumber pencemar); Stasion 4 dan 5, yaitu sungai Waelata I, Sungai Waelata II terdapat kegiatan di darat (pemukiman, pertambangan); Stasion 6 (Muara Waeapo) terdapat mangrove dan kegiatan darat (pemukiman, pertambangan) dan Stasion 7,8 dan 9 (sungai Sanleko, sungai Marlosso dan Pantai Nametek) terdapat lamun dan kegiatan di darat (pertambangan menggunakan tromol, pemukiman penduduk, dermaga). Pada masing-masing stasion dilakukan pengukuran parameter fisik-kimia air, pengambilan sampel air, sedimen dan 
tumbuhan lamun. Pengambilan sampel air dilakukan dengan menggunakan botol polietilen mengacu pada SNI 6989.57:2008. Sebelum melakukan pengambilan sampel terlebih dahulu dilakukan pengukuran parameter fisik kimia seperti suhu, $\mathrm{pH}$, salinitas,kedalaman, kekeruhan dan kecerahan.

Pengambilan sampel air langsung menggunakan botol sampel pada kedalaman \pm $30 \mathrm{~cm}$ di setiap titik. Sampel air yang akan diukur kadar logam beratnya ( $\mathrm{Pb}$ dan $\mathrm{Hg}$ ) ditambahkan $\mathrm{HNO}_{3}$ sebagai pengawet sampai $\mathrm{pH}<2$ kemudian disimpan dalam cool box selanjutnya dibawa ke laboratorium untuk dianalisis. Sampel sedimen diambil dengan menggunakan ekman grab. Sedimen diambil sebanyak 300 gram lalu dimasukkan ke dalam plastik polietilen dan dan disimpan dalam cool box selanjutnya dibawa ke laboratorium untuk dianalisis kandungan $\mathrm{Pb}$ dan $\mathrm{Hg}$. Pengambilan sampel lamun dilakukan dengan menggunakan alat linggis dan tropol kemudian dicabut perlahan-lahan agar lamun tidak rusak. Sampel lamun Enhalus acoroides diambil di perairan Teluk Kayeli yang terdapat lamun. Sampel lamun dimasukkan ke dalam kantong plastik, lalu disimpan dalam cool box dan dibawa ke laboratorium untuk preparasi sebelum dianalisis kandungan logam berat ( $\mathrm{Pb}$ dan $\mathrm{Hg}$ ) pada organ akar, rhizoma dan lamun.

\section{Analisis Kandungan Logam Berat Pb dan $\mathrm{Hg}$}

Sampel Enhalus acoroides diambil pada 2 Stasion pengamatan (Marlosso dan Jikumerasa) dimana terdapat lamun (dari 10 Stasion pengamatan). Analisis kandungan logam berat pada sampel air adalah diambil 10-25 ml kemudian dilakukan ekstraksi: Masukkan sampel ke dalam tabung digestion. Ditambahkan $5 \mathrm{ml} \mathrm{HNO}_{3}$ p.a. dan 0,5 $\mathrm{ml}$ $\mathrm{HClO}_{4}$ p.a. dan biarkan satu malam. Besoknya dipanaskan dalam digestions blok dengan suhu $100{ }^{\circ} \mathrm{C}$ selama satu jam, kemudian suhu ditingkatkan menjadi $150{ }^{\circ} \mathrm{C}$. Setelah uap kuning habis, suhu digestion blok ditingkatkan menjadi $200{ }^{\circ} \mathrm{C}$. Destruksi selesai setelah keluar asap putih dan sisa ekstrak kurang lebih $0,5 \mathrm{ml}$. Tabung diangkat dan dibiarkan dingin. Ekstrak diencerkan dengan air bebas ion hingga volume tepat $50 \mathrm{ml}$ dan kocok dengan pengocok tabung hingga homogen. Ekstrak ini dapat digunakan untuk pengukuran unsur-unsur makro dan mikro. Untuk standar tanpa melewati proses pengabuan. Sampel dianalisis menggunakan Atomic Absorption Spectrofotometer (AAS). Alat dan metode yang digunakan untuk ekstraksi dan analisis logam berat timbal dan merkuri pada air dan sedimen sama dengan pada organ lamun.

Data kandungan logam berat $\mathrm{Pb}$ dan $\mathrm{Hg}$ yang diperoleh ditampilkan dalam bentuk tabel, grafik dan histogram kemudian dibahas secara deskriptif. Hasil analisis logam berat $\mathrm{Pb}$ dan $\mathrm{Hg}$ dalam air pada titik pengambilan sampel dibandingkan dengan nilai standar yang ditetapkan oleh Pemerintah melalui Keputusan Menteri Lingkungan Hidup No. 51 Tahun 2004 tentang penetapan Baku Mutu Air Laut untuk Biota Lautll. Kandungan logam berat $\mathrm{Pb}$ dan $\mathrm{Hg}$ dalam sedimen dibandingkan dengan standar baku mutu CCME, ANZECC dan NOAA. Kandungan logam berat $\mathrm{Pb}$ dan $\mathrm{Hg}$ dalam organ lamun dibandingkan dengan baku mutu SNI 7387:2009. Analisis Multifaktorial ANOVA (Two 
Way ANOVA p < 0,05) juga digunakan untuk mengetahui: perbedaan akumulasi logam berat $\mathrm{Pb}$ dan $\mathrm{Hg}$ pada masing-masing titik lokasi pengambilan sampel. Selain itu Two Way ANOVA $\mathrm{p}<0,05$ digunakan untuk mengetahui perbedaan akumulasi logam $\mathrm{Pb}$ dan Hg pada akar, rhizoma dan daun.

\section{HASIL DAN PEMBAHASAN}

\section{Kandungan Logam Berat $\mathrm{Pb}$ dan $\mathrm{Hg}$ pada Air dan Sedimen}

Hasil analisis Two-way ANOVA menunjukkan bahwa logam berat $\mathrm{Pb}$ berbeda signifikan $(\mathrm{P}<0,005)$ antara sedimen dan air di perairan Teluk Kayeli. Kandungan ratarata $\mathrm{Pb}$ tertinggi terdapat pada sedimen $(1,2818 \mathrm{mg} / \mathrm{Kg})$ dibandingkan dengan air $(1,2186$ $\mathrm{mg} / \mathrm{L})$

Tabel 1. Perbedaan kandungan $\mathrm{Pb}$ pada sedimen dan air

Grouping Information Using Tukey Method and 95,0\% Confidence

Pengamatan N Mean Grouping

Sedimen $\quad 60 \quad 1,2818 \quad \mathrm{~A}$

Air $\quad 60 \quad 1,2186 \quad$ B

Means that do not share a letter are significantly differe

Hasil pengukuran kandungan $\mathrm{Pb}$ dalam air laut di perairan Teluk Kayeli pada 10 stasion pengamatan berkisar antara $0,005 \pm 0,0005 \mathrm{mg} / \mathrm{L}-0,023 \pm 0,0005 \mathrm{mg} / \mathrm{L}$ (Gambar $1)$.

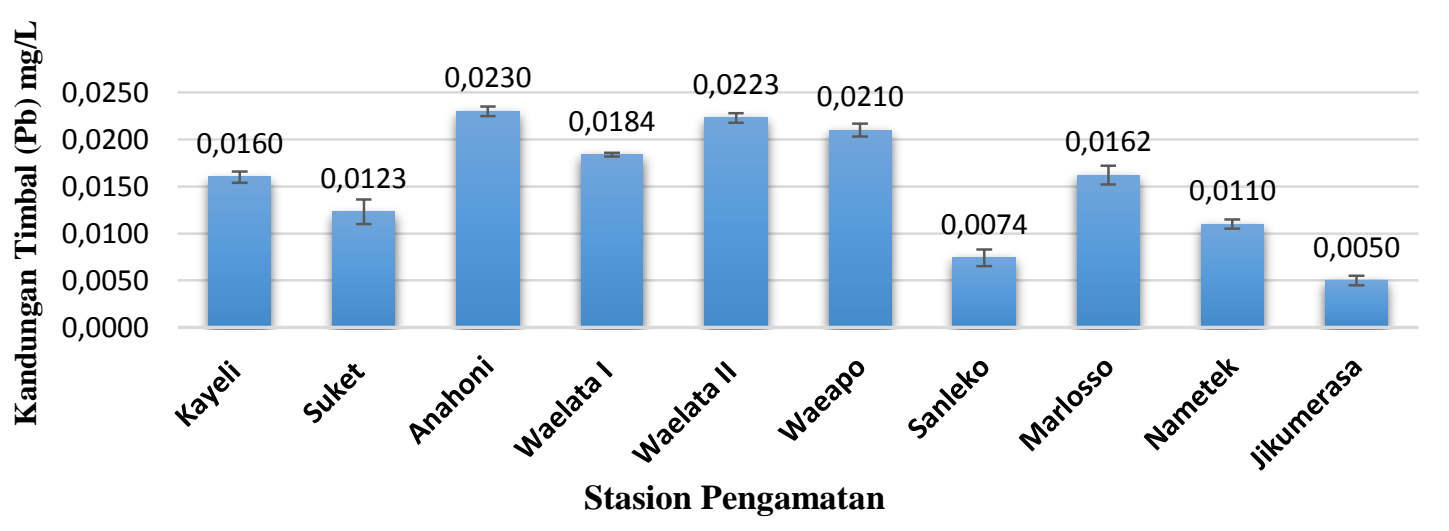

Gambar 1. Kandungan timbal (Pb) pada air

Hasil pengukuran kandungan $\mathrm{Pb}$ pada sedimen di perairan Teluk Kayeli menunjukkan kisaran antara 0,4789 $\pm 0,01913-1,8514 \pm 0,07471 \mathrm{mg} / \mathrm{Kg}(\mathrm{Gambar} 2)$ 


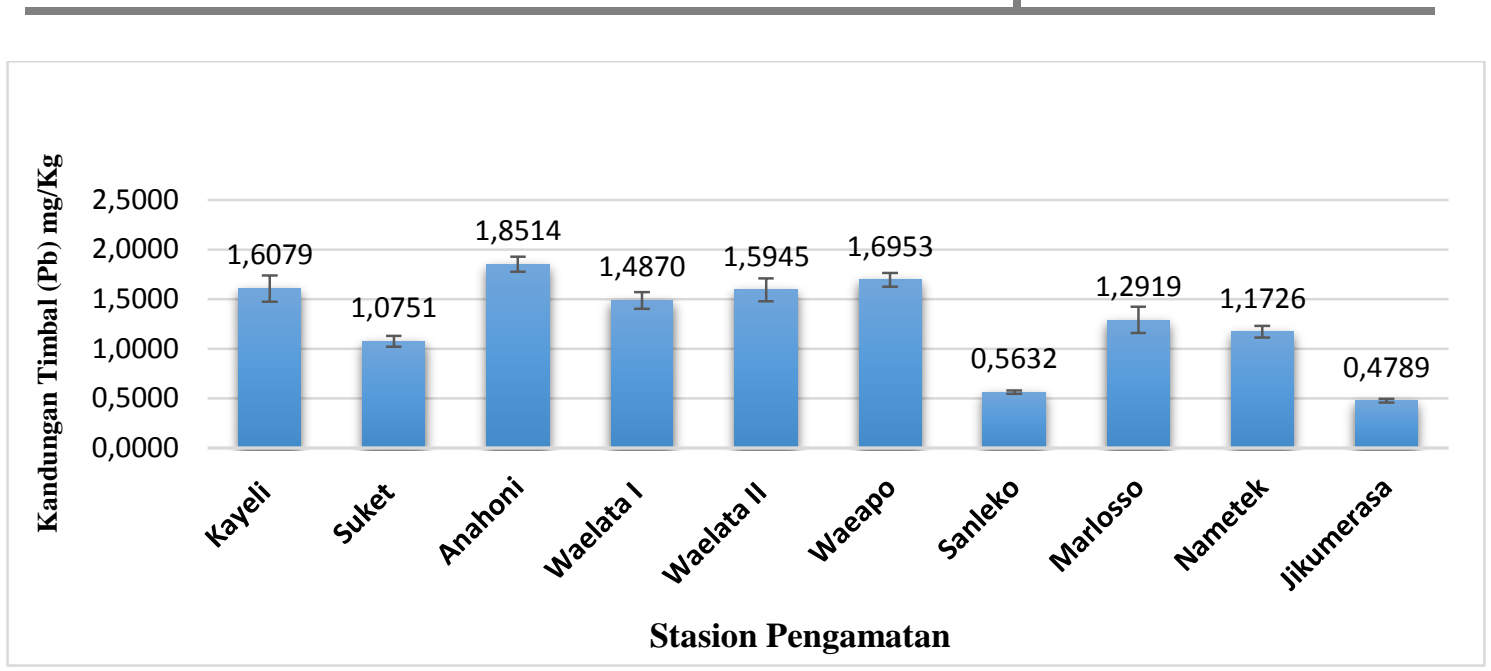

Gambar 2. Konsentrasi timbal ( $\mathrm{Pb})$ pada sedimen

Hasil analisis Two-way ANOVA menunjukkan bahwa logam berat $\mathrm{Hg}$ berbeda signifikan $(\mathrm{P}<0,05)$ dan menunjukkan adanya perbedaan kandungan $\mathrm{Hg}$ antara sedimen $(0,501$ $\mathrm{mg} / \mathrm{L})$ dan air $(0,003 \mathrm{mg} / \mathrm{L})$ di perairan Teluk Kayeli.

Tabel 2. Perbedaan kandungan Hg pada sedimen dan air

\begin{tabular}{llcc}
\multicolumn{4}{c}{ Grouping Information Using Tukey Method and $95,0 \%$ Confidence } \\
Pengamatan & $\mathrm{N}$ & Mean & Grouping \\
Sedimen & 60 & 0,501 & A \\
Air & 60 & 0,003 & B \\
\hline
\end{tabular}

Hasil pengukuran setiap stasion menunjukkan kandungan $\mathrm{Hg}$ pada air berkisar antara $0,001 \pm 0,00012-0,005 \pm 0,00012 \mathrm{mg} / \mathrm{L}$ (Gambar 3).

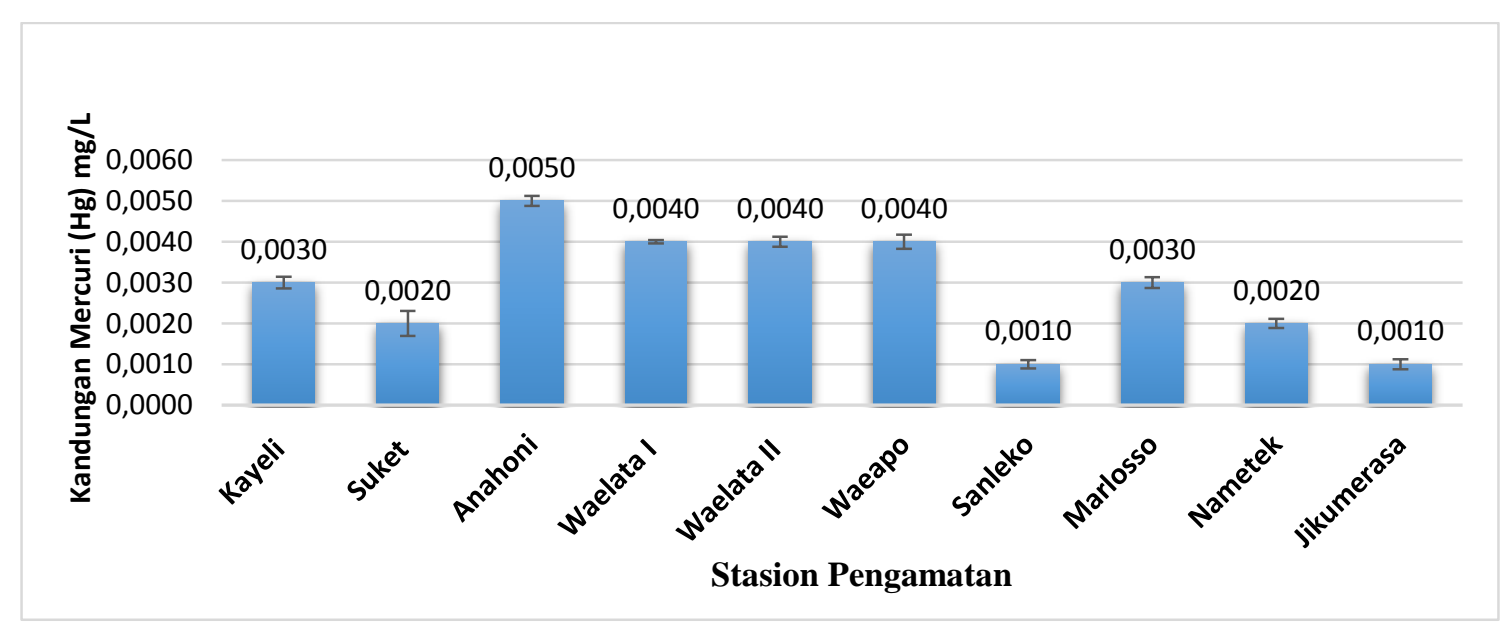

Gambar 3. Kandungan merkuri pada air

Hasil pengukuran setiap stasion menunjukkan sedimen berkisar antara $0,001 \pm 0,023-$ $1,835 \pm 0,16828 \mathrm{mg} / \mathrm{kg}$ (Gambar 4). 


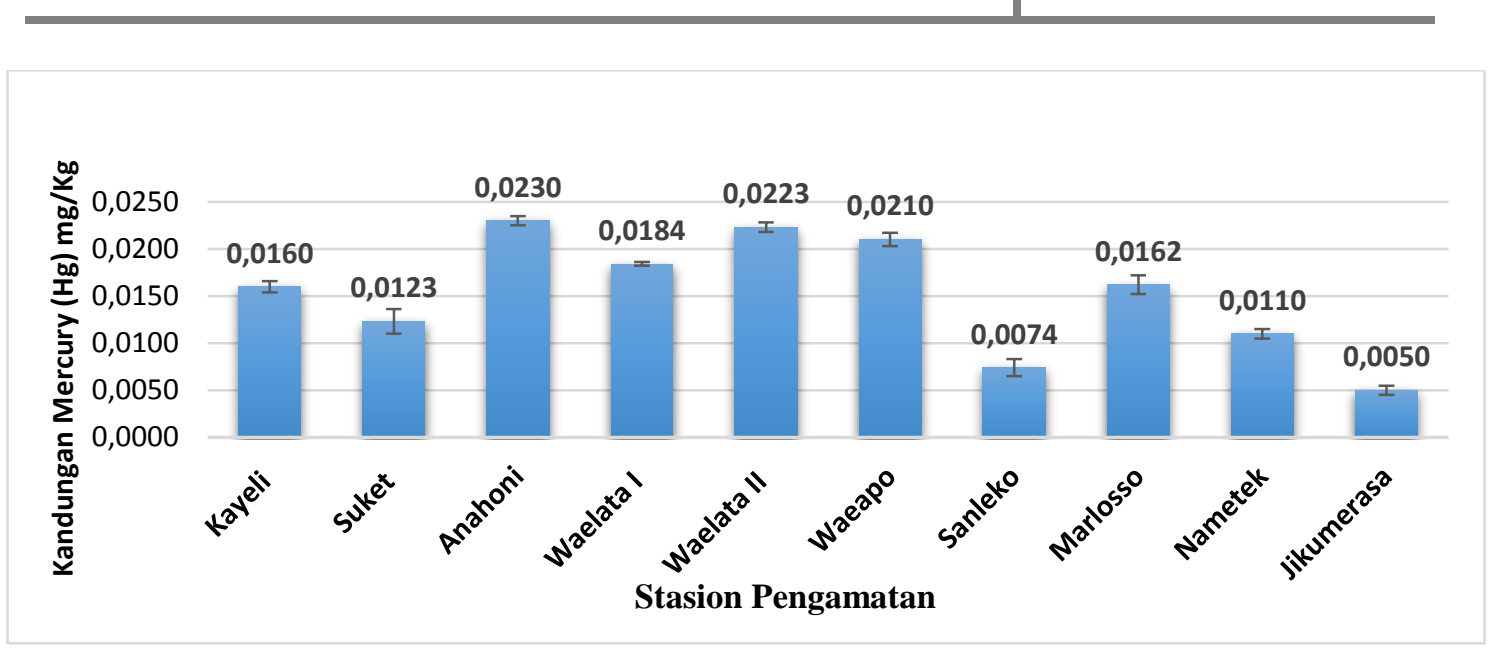

Gambar 4. Kandungan merkuri pada sedimen

\section{Kandungan Logam Berat pada Organ (Akar, Rhizoma dan Daun) Lamun (Enhalus acoroides)}

Hasil penelitian di perairan Teluk Kayeli terindikasi bahwa Lamun (Enhalus acoroides) terdapat pada titik sampling 8 (Muara Sungai Marlosso) dan titik sampling 10 (Pantai Jikumerasa). Tabel 3 menunjukkan perbedaan kandungan logam berat baik $\mathrm{Pb}$ maupun Hg pada organ lamun (Enhalus acoroides) di dua (2) titik sampling.

Tabel 3. Kandungan logam berat $\mathrm{Pb}$ dan $\mathrm{Hg}$ pada akar, rhizoma dan daun Lamun (Enhalus acoroides) di Titik Sampling 8 (Marlosso) dan Titik Sampling 10 (Jikumerasa)

\begin{tabular}{|c|c|c|c|c|c|c|c|}
\hline \multirow{2}{*}{$\begin{array}{c}\text { Titik } \\
\text { Sampling }\end{array}$} & \multirow[t]{2}{*}{ Lokasi } & \multicolumn{2}{|c|}{ Akar } & \multicolumn{2}{|c|}{ Rhizoma } & \multicolumn{2}{|c|}{ Daun } \\
\hline & & $\begin{array}{c}\mathrm{Pb} \\
(\mathrm{mg} / \mathrm{Kg})\end{array}$ & $\begin{array}{c}\mathrm{Hg} \\
(\mathrm{mg} / \mathrm{Kg})\end{array}$ & $\begin{array}{c}\mathrm{Pb} \\
(\mathrm{mg} / \mathrm{Kg})\end{array}$ & $\begin{array}{c}\mathrm{Hg} \\
(\mathrm{mg} / \mathrm{Kg})\end{array}$ & $\begin{array}{c}\mathrm{Pb} \\
(\mathrm{mg} / \mathrm{Kg})\end{array}$ & $\begin{array}{c}\mathrm{Hg} \\
(\mathrm{mg} / \mathrm{Kg})\end{array}$ \\
\hline 8 & $\begin{array}{l}\text { Muara } \\
\text { Sungai } \\
\text { Marlosso }\end{array}$ & $\begin{array}{c}\mathrm{b} 5,3266 \pm 0,055 \\
8\end{array}$ & $\begin{array}{c}\mathrm{b} 0,6687 \pm 0, \\
0069\end{array}$ & 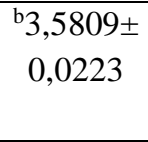 & $\begin{array}{c}0,4772 \pm \\
0,0080\end{array}$ & $\begin{array}{c}\mathrm{b}_{1,7981 \pm} \\
0,0360\end{array}$ & $\begin{array}{c}0,2717 \pm 0 \\
, 0088\end{array}$ \\
\hline 10 & $\begin{array}{l}\text { Pantai } \\
\text { Jikumerasa }\end{array}$ & $\begin{array}{c}\mathrm{b} 2,7449 \pm 0,027 \\
1\end{array}$ & $\begin{array}{l}0,1782 \pm \\
0,00867\end{array}$ & $\begin{array}{c}\text { b } 1,9271 \pm \\
0,0363\end{array}$ & $\begin{array}{c}0,1099 \pm \\
0,0105\end{array}$ & $\begin{array}{c}{ }^{\mathrm{b}} 0,7985 \pm \\
0,0351\end{array}$ & $\begin{array}{c}0,0576 \pm 0 \\
, 0040\end{array}$ \\
\hline \multicolumn{2}{|c|}{ Rata-rata } & $\mathrm{b}_{4,03375}$ & 0,4235 & b2,754 & 0,2935 & $\mathrm{~b}_{1,2983}$ & 0,165 \\
\hline \multicolumn{2}{|c|}{${ }^{\mathrm{a} B a k u}$ mutu } & 0,3 & 0,5 & 0,3 & 0,5 & 0,3 & 0,5 \\
\hline
\end{tabular}

Keterangan : ${ }^{a}$ SNI 7387:2009; ${ }^{\text {b} M e l e b i h i ~ b a k u ~ m u t u ~ T S ~=~ T i t i k ~ S a m p l i n g ~}$

\section{Kandungan Logam Berat $\mathrm{Pb}$ dan $\mathrm{Hg}$ pada Air dan Sedimen}

Hasil analisis menunjukkan bahwa kandungan $\mathrm{Pb}$ berbeda pada sedimen dan air. Kandungan $\mathrm{Pb}$ tertinggi terdapat pada sedimen $(1,2818 \mathrm{mg} / \mathrm{Kg})$ dibandingan dengan air $(1,2186 \mathrm{mg} / \mathrm{l})$. Selaras dengan Tupan et al (2014) dalam penelitiannya menyatakan bahwa kandungan logam $\mathrm{Pb}$ pada sedimen lebih tinggi daripada di air dan berkorelasi significan dengan akar lamun Thalassia hemprichii. Logam berat yang masuk dalam tanah (sedimen) dan sebagian akan masuk dalam sistem aliran sungai yang selanjutnya akan terbawa ke laut. Logam berat yang masuk dalam ekosistem laut akan mengendap ke dasar perairan dan terserap dalam sedimen (Jaibet, 2007). 
Kandungan logam berat $\mathrm{Pb}$ di perairan Teluk Kayeli menunjukkan hasil melebihi nilai baku mutu logam timbal pada air laut yang ditetapkan dalam KepMen LH No. 51 Tahun 2004 tentang baku mutu air laut bagi biota laut sebesar 0,008 mg/l. Kandungan timbal yang tinggi dalam perairan Teluk Kayeli akan berdampak pada terganggunya kehidupan biota perairan. Logam berat dalam perairan tersebut selanjutnya terabsorbsi dalam tanaman akuatik dan akan terkontaminasi ke plankton dan biota mikrooranisme lainnya dalam air (Riani, 2012). Sedimen dan tanah dikenal sebagai "storage system", sehingga bahan pencemar termasuk $\mathrm{Pb}$ yang masuk ke sistem ini akan terendap. Kandungan logam berat $\mathrm{Pb}$ pada sedimen menunjukkan hasil masih di bawah batas aman toleransi apabila dibandingkan dengan baku mutu (CCME $2002=30,2 \mathrm{mg} / \mathrm{Kg}$ ). Namun demikian pengendapan logam berat yang terus berlangsung di Teluk Kayeli dapat berakibat pada peningkatan timbal yang berlebih di sedimen. Hal ini seiring waktu dengan bertambahnya jumlah aktivitas pertambangan emas di sepanjang perairan Teluk Kayeli, berpotensi akan semakin tinggi pula kadar timbal di air sungai yang akan masuk ke laut.

Hasil analisis menunjukkan bahwa kandungan $\mathrm{Hg}$ berbeda pada sedimen dan air. Kandungan $\mathrm{Hg}$ tertinggi terdapat pada sedimen $(0,501 \mathrm{mg} / \mathrm{Kg})$ dibandingan dengan air $(0,003 \mathrm{mg} / \mathrm{L})$. Hasil analisis di atas terlihat bahwa konsentrasi merkuri $(\mathrm{Hg})$ di sedimen lebih besar daripada di air. Hal ini dikarenakan merkuri memiliki sifat kimia yang stabil terutama di lingkungan sedimen. Selain itu setelah merkuri masuk ke dalam perairan, merkuri tersebut sebagian ada yang terbawa aliran air, ada juga yang masuk terserap oleh tumbuhan air melalui akar dan bertransformasi di dalam sistem metabolisme tumbuhan air. Thomas and Young (1988) menyebutkan bahwa sedimen sebagai tempat penyimpanan logam berat B3 yang cukup potensial di wilayah pesisir.

Hasil analisis menunjukkan kandungan logam berat merkuri $(\mathrm{Hg})$ dalam air laut di setiap titik sampling telah melebih baku mutu untuk organisme perairan. Nilai baku mutu logam berat merkuri dalam air laut diatur dalam KepMen LH No. 51 Tahun 2004 tentang baku mutu air laut bagi biota laut sebesar 0,001 mg/L. Hal ini diduga karena hasil dari aktivitas pertambangan emas tradisional di bagian hulu sungai Waeapo. Pengolahan emas yang menggunakan cairan merkuri pada proses amalgamasi berpotensi mencemari lingkungan apabila tidak dikelola secara benar. Penggunaan merkuri secara liar pada pengolahan biji emas (tromol/tailing) tanpa memperhatikan prinsip-prinsip pengolahan limbah akan berdampak buruk terhadap lingkungan khususnya tanah di sekitar daerah pengolahan. Hal ini sejalan dengan penelitian (Mirdat et al. 2013) yang menemukan kandungan merkuri $(\mathrm{Hg})$ dalam tanah pada areal sekitar tromol/tailing di Kelurahan Poboya berkisar 0,57 ppm - 8,19 ppm sedangkan pada limbah berkisar 84,15 ppm sampai 575,16 ppm.

Aktivitas pengolahan emas yang menggunakan cairan merkuri tanpa memperhatikan akibatnya akan menghasilkan lumpur dengan kandungan merkuri yang 
tinggi. Lumpur yang dihasilkan oleh aktivitas tailing tersebut tidak dikelola secara benar, hanya ditampung dalam kolam penampungan yang kecil, sehingga ketika turun hujan maka akan terbawa ke sungai selanjutnya mengalir ke laut. Sebagian lainnnya akan menguap ke udara dan ketika turun hujan maka akan terbawa turun bersama air hujan. Hal inilah yang diduga menjadi penyebab akan semakin bertambahnya kandungan merkuri dalam sedimen di Teluk Kayeli. Kontaminasi logam berat merkuri pada sedimen di Teluk Kayeli diduga juga berasal dari sumber lain seperti limbah rumah tangga, dari penggunaan pestisida oleh masyarakat pada bidang pertanian dan perkebunan di daratan. Limbah rumah tangga mengandung $\mathrm{Hg}$ dan dapat terakumulasi dalam sedimen. Merkuri yang menguap dapat bertahan di atmosfer selama satu tahun (Anonim,2011). Merkuri $(\mathrm{Hg})$ yang terdapat dalam limbah (waste) di perairan umumnya akan diubah oleh aktivitas mikroorganisme menjadi komponen metil-merkuri (Me-Hg) yang memiliki sifat racun dan mempunyai daya ikat yang kuat disamping kelarutannya yang tinggi (Purnawan et al, 2013).

\section{Kandungan Logam Berat pada Akar, Rhizoma dan Daun Enhalus acoroides}

Hasil penelitian terhadap kandungan logam berat pada lamun (Enhalus acoroides) di perairan Teluk Kayeli pada stasion 8 (Muara Sungai Marlosso) dan 10 (Pantai Jikumerasa), menunjukkan terdapat perbedaan kandungan logam berat baik $\mathrm{Pb}$ maupun $\mathrm{Hg}$ pada akar, rhizome dan daun lamun di 2 (dua) stasion tersebut (Tabel 1). Kandungan $\mathrm{Pb}$ pada akar $(5,3266 \pm 0,05579 \mathrm{mg} / \mathrm{Kg})$ lebih tinggi pada stasion 8 dibandingkan stasion $10(2,7449 \pm 0,02713 \mathrm{mg} / \mathrm{Kg})$. Nilai baku mutu logam berat timbal yaitu $0,3 \mathrm{mg} / \mathrm{Kg}$ (SNI 7387:2009) dan 0,4 mg/Kg (BPOM). Berdasarkan hasil kandungan logam berat timbal pada akar di Teluk Kayeli menyatakan bahwa telah melewati baku mutu yang ditetapkan pemerintah. Konsentrasi timbal yang tinggi pada akar lamun diduga logam $\mathrm{Pb}$ terserap dalam bentuk ion-ion. Logam akan larut dalam lemak dan mampu melakukan penetrasi pada membran sel, sehingga ion logam akan terakumulasi di dalam sel dan jaringan. Kandungan $\mathrm{Pb}$ pada rhizoma lamun pada stasion 8 (Muara Sungai Marlosso) lebih tinggi $(3,5809 \pm 0,02233 \mathrm{mg} / \mathrm{Kg})$ dibandingkan dengan stasion $10(1,9271 \pm 0,03634 \mathrm{mg} / \mathrm{Kg})$. Nilai baku mutu logam berat timbal pada biota laut sebesar 0,3 mg/Kg (SNI 7387:2009) dan $0,4 \mathrm{mg} / \mathrm{Kg}$ (BPOM).

Kandungan logam berat timbal pada rhizoma yang diperoleh dari lokasi penelitian telah melewati batas baku mutu yang ditetapkan oleh pemerintah sesuai SNI dan BPOM. $\mathrm{Hal}$ ini diduga penyerapan logam $\mathrm{Pb}$ oleh tanaman melalui akar meningkat dari substrat tempat tumbuhnya. Kandungan $\mathrm{Pb}$ yang tinggi pada stasion 8 di perairan Sungai Marlosso akan menyebabkan peran rhizoma lamun menjadi terganggu. Kandungan $\mathrm{Pb}$ di daun pada stasiun 8 (Muara Sungai Marlosso) lebih tinggi $(1,7981 \pm 0,03602 \mathrm{mg} / \mathrm{Kg}$ ) dibandingkan dengan stasiun $10(0,7985 \pm 0,03515 \mathrm{mg} / \mathrm{Kg})$. Nilai baku mutu logam berat timbal pada biota laut sebesar 0,3 mg/Kg (SNI 7387:2009) dan 0,4 mg/Kg (BPOM). Kandungan logam berat timbal pada daun yang diperoleh dari lokasi penelitian baik di Muara Sungai 
Marlosso maupun Jikumerasa telah melewati batas baku mutu yang ditetapkan oleh pemerintah sesuai SNI dan BPOM. Kandungan Pb yang tinggi di daun pada kedua stasiun (8 dan 10) di duga bahwa $\mathrm{Pb}$ sebagian besar terakumulasi di daun. Disamping itu perpindahan $\mathrm{Pb}$ dari tanah ke tanaman juga tergantung dari komposisi dan $\mathrm{pH}$ tanah. Konsentrasi $\mathrm{Pb}$ yang tinggi akan mengakibatkan pengaruh toksik pada proses fotosintesis dan pertumbuhan. $\mathrm{Pb}$ mempengaruhi tanaman dalam konsentrasinya tinggi. Tanaman dapat menyerap logam $\mathrm{Pb}$ pada saat kondisi kesuburan dan kandungan bahan organik tanah rendah.

Kandungan logam $\mathrm{Hg}$ di akar lamun pada dua stasion 8 dan 10 adalah sebesar $0,6687 \pm 0,0069 \mathrm{mg} / \mathrm{Kg}$ dan $0,1782 \pm 0,0087 \mathrm{mg} / \mathrm{Kg}$. Konsentrasi tertinggi diperoleh pada stasion 8 dan terendah pada stasion 10. Nilai baku mutu logam berat merkuri pada lamun sebesar 0,5 mg/Kg (SNI 7387:2009) dan 1,0 mg/Kg (BPOM). Kandungan $\mathrm{Hg}$ yg didapatkan dalam organ lamun (akar) masih pada batas toleransi bagi tumbuhan untuk stasion 10 ( Pantai Jikumerasa), namun kandungan ini masih dianggap berbahaya bagi tumbuhan karena merkuri dimungkinkan akan diangkut melalui jaringan pengangkut xilem dan floem ke bagian tumbuhan lain. Dalam meningkatkan efisiensi pengangkutan dalam organ tanaman, logam diikat oleh molekul khelat. Berbagai jenis molekul khelat yang berfungsi mengikat logam dihasilkan oleh tumbuhan seperti histidin yang dapat mengikat Cr. Lokasi pada jaringan dalam mencegah peracunan logam terhadap sel, tumbuhan mempunyai mekanisme detoksifikasi. Kandungan $\mathrm{Hg}$ yang tinggi pada akar pada stasion 8 diduga karena terdapatnya kegiatan pertambangan emas di dekatnya yang telah terlebih dahulu mencemari tanah dan air sungai di sekitarnya. Respon pertama tumbuhan adalah pada akar. Terdapat juga serangkaian proses fisiologis yang berperan dalam akumulasi logam sepanjang siklus hidup tumbuhan yang berawal dari akar.

Kandungan $\mathrm{Hg}$ pada rhizoma pada stasion 8 lebih tinggi $(0,4772 \pm 0,0080 \mathrm{mg} / \mathrm{Kg})$ dibandingkan dengan stasion $10(0,1099 \pm 0,0105 \mathrm{mg} / \mathrm{Kg})$. Nilai baku mutu logam berat merkuri pada lamun sebesar 0,5 mg/Kg (SNI 7387:2009) dan 1,0 mg/Kg (BPOM). Ratarata hasil analisis laboratorium logam merkuri pada rhizoma yang diperoleh dari lokasi penelitian masih berada dibawah baku mutu yang ditetapkan pemerintah. Meskipun kandungan logam merkuri $(\mathrm{Hg})$ dalam sampel rhizoma masih dalam konsentrasi yang sangat kecil namun peningkatan kandungan logam ini perlu diwaspadai dikarenakan peran dari tumbuhan sebagai produsen utama dalam sistem rantai makanan. Konsentrasi $\mathrm{Hg}$ tidak mustahil akan menjadi besar (terakumulasi) pada biota dengan trofik level yang lebih tinggi. Kandungan merkuri $(\mathrm{Hg})$ pada daun yang terdapat pada stasion 8 sebesar $0,2717 \pm 0,0088 \mathrm{mg} / \mathrm{Kg}$ dan stasion 10 sebesar $0,0576 \pm 0,0040 \mathrm{mg} / \mathrm{Kg}$ masih dalam batas normal namun demikian kandungan $\mathrm{Hg}$ pada stasion 8 sudah mendekati batas kritis dan dikhawatirkan meningkat sejalan dengan polutan yang masuk secara berkala dari aktivitas di sekitar perairan. 


\section{KESIMPULAN}

Hasil kandungan logam berat $\mathrm{Pb}$ dan $\mathrm{Hg}$ pada air, sedimen dan organ lamun (akar, rhizoma dan daun) lamun Enhalus acoroides di perairan Teluk Kayeli menunjukkan bahwa akumulasi $\mathrm{Pb}$ dan $\mathrm{Hg}$ lebih banyak terdapat pada sedimen dan akar lamun.

\section{DAFTAR PUSTAKA}

Agus C, Sukandarrumidi, Wintolo D. (2005). Dampak limbah cair pengolahan emas terhadap kualitas air sungai dan cara mengurangi dampak dengan menggunakan zeolit: studi kasus pertambangan emas tradisional di desa Jendi Kecamatan Selogiri Kabupaten Wonogiri Provinsi Jawa Tengah. Jurnal Manusia dan Lingkungan, Vol. 12, No.1, Maret 2005, hal. I3-19 Pusat Studi Lingkungan Hidup Universitas Gadjah Mada. Yogyakarta, Indonesia

Ahmad, F., S. Azman, M.I. Mohd Said, L. Baloo. (2015). Tropical seagrass as a bioindicator of metal accumulation. Sains Malaysiana, 44(2): 203-210.

Ambo-Rappe, R., D.L. Lajus, M.J. Schreider. (2011). Heavy metal impact on growth and leaf asymmetry of seagrass, Halophila ovalis. Journal of Environmental Chemistry and Ecotoxicology, 3(6): 149-159.

Azkab, H. (2006). Ada Apa dengan Lamun. J. Oseana., 31(3):45-55.

Björk M, Short F, Mcleod E, Beer S. 2008. Managing Seagrasses for Resilience to Climate Change: IUCN, Gland, Switzerland.

Boran M \& Altinok I. 2010. A Review of Heavy Metals in Water, Sediment and Living Oganisms in The Black Sea. Turkish Journal of Fisheries and Aquatic Science 10: $565-572$

Campbell, P. 2002. Predicting metal bioavailability-applicability of the Biotic Ligand Model; CIESM Workshop Monographs Metal and radionuclides bioaccumulation in marine organisms; CIESM, Monaco.

Endang, Y.H. 2008. Lamun (Cymodocea rotundata, Thalassia hemprichii dan Enhalus acoroides) sebagai Bioindikator Logam Berat Timbal (Pb) di Perairan Pesisir. Disertasi. Fakultas Perikanan dan Ilmu Kelautan. Universitas Brawijaya. Malang

Fisher, N. 2003. Advantage and Problems in The Application of Radiotracer for Determining The Bioaccumulation of Contaminant in Aquatic Organism. RCM on Biomonitoring, IAEA, Monaco

Jaibet, J. 2007. Analisis LOgam Berat Cd, Cu dan Pb dalam Sedimen dan Air Laut di Teluk Salut Tuaran. Thesis (Tidak dipublikasikan). Sekolah Sains dan Teknologi. Universitas Malaysia Sabah

Maddusa,S.S, M Giffari P, A.R. Syarifuddin, J Maambuat, G.Alla.2017.Kandungan Lgam Berat Timbal (Pb), Merkuri (Hg), Zink (Zn) dan Arsen (As) pada Ikan dan Air Sungai Tondano, Sulawesi Utara. Al-Sihah: Public Health Science Journal. VOLUME IX, NO. 2, JULI -DESEMBER 2017 
Ning L, Liyuan Y, Jirui D, Xugui P. (2011). Heavy metal pollution in surface water of Linglong Gold Mining Area, China. Procedia Environment Sciences. 10: 914917.

Rainbow PS. (2007). Trace bioaccumulation: models, metabolic availability and toxicity. Environment International 33, 576-582.

Riani. (2012). Perubahan Iklim dan Kehidupan Biota Akuatik (Dampak pada Bioakumulasi Bahan Berbahaya dan Beracun \&Reproduksi). IPB Press. Bogor.

Rijal, M., Rosmawati, T., Alim, N., \& Amin, M. (2014). Bioakumulation heavy metals lead $(\mathrm{Pb})$ and cadmium $(\mathrm{Cd})$ seagrass (Enhalus acroides) in Waai and Galala Island Ambon. IJSBAR, 16(2), 349-356

Rijal, M. (2010). Bioakumulasi Logam Berat Timbal (Pb) dan Cadmium (Cd) pada Lamun (Enhalus Acroides) Di Perairan Waai dan Galala Ambon Sebagai Sumber Belajar Ekologi Pencemaran. (Tesis). DISERTASI dan TESIS Program Pascasarjana UM

Sudharsan, S., P. Seedevi, P. Ramasamy, N. Subhapradha, S. Vairamani, A. Shanmugam. (2012). Heavy metal accumulation in seaweeds and sea grasses along southeast coast of India. Journal of Chemical and Pharmaceutical Research, 4(9): 42404244.

Supriyantini, E., S. Sedjati, Z. Nurfadhli. (2016). Akumulasi logam berat Zn (seng) pada lamun Enhalus acoroides dan Thalassia hemprichii di Perairan Pantai Kartini Jepara. Buletin Oseanografi Marina, 5(1): 14-20.

Tuaputty, Una.S. (2014). Eksternalitas Pertambangan Emas Rakyat di Kabupaten Buru Maluku. Tesis (Tidak dipublikasikan). IPB. Bogor.

Tupan, Charlotha I. E. Y. Herawati, D. Arfiati. Aulanni'am. (2014). Profile of lead (Pb) heavy metal in water, sediment and seagrass (Thalassia hemprichii) in Ambon Island, Maluku, Indonesia. Journal of Biodiversity and Environmental Sciences (JBES) ISSN: 2220-6663 (Print) 2222-3045 (Online) Vol. 5, No. 4, p. 65-73, 2014

Tupan, C. I., R. Azrianingsih. (2016). Accumulation and deposition of lead heavy metal in the tissues of roots, rhizomes and leaves of seagrass Thalassia hemprichii (Monocotyledoneae, Hydrocharitaceae). AACL Bioflux, 9(3): 580-589. Unsworth RKF, Collier CJ, Waycott M, McKenzie LJ, Cullen

Thangaradjou, T., E.P. Nobi, E. Dilipan, K. Sivakumar, S. Susila. (2011). Heavy metal enrichment in seagrasses of Andaman Islands and its implication to the health of the coastal ecosystem. Indian Journal of Marine Sciences, 39(1): 85-91.

Wulandari E, Herawati EY, Arfiati D. (2012). Kandungan logam berat Pb pada air laut dan tiram Saccostrea glomerata sebagai bioinkator kualitas Perairan PrigiTrenggalek, Jawa Timur. Jurnal Penelitian Perikanan. 1(1): 10-14. 